\title{
Legal Standing of Finance and Development Supervisory Agency (BPKP) in Calculating State Financial Losses in the Case of the Corruption Crime (Case Study of Decision Number: 31/Pid.Sus/TPK/2017/PN. Pdg)
}

\author{
Yuharmen Yakub; Elwi Danil; Aria Zurnetti \\ Faculty of Law, Andalas University, Padang, Indonesia \\ http://dx.doi.org/10.18415/ijmmu.v6i3.930
}

\begin{abstract}
Finance and Development Supervisory Agency (BPKP) is one of the institutions stipulated in Presidential Regulation of the Republic of Indonesia No. 192 of 2014 in charge of organizing government affairs in the field of state/ regional financial supervision and national development. This research raises several problems which include: First, what is the form of regulation of BPKP's authority in legislation related to audits in calculating state financial losses in the case of corruption crime. Second, how is the legal standing of the BPKP Representative of West Sumatra Province in calculating state financial losses in the decision Number: 31/Pid.Sus/TPK/2017/PN Pdg on behalf of the defendant Vera Aldilla Roza, ST related to corruption crime in Padang District Court. This is a normative juridical research which applied an approach to legislation (statute approach) and to the case (case approach). This research used a technique in the form of a library study that utilized primary, secondary, and tertiary legal materials. The legal materials were then analyzed qualitatively to answer the problems discussed in this research. Based on the results of the research, it was concluded that the legal standing of BPKP was in the executive power. In this case, the regulation of authority related to calculating state financial losses contained in the legislation, i.e. Presidential Regulation No. 192 of 2014 concerning BPKP. In addition, this authority was strengthened by the Decision of the Constitutional Court Number: 31/PUU-X/2012 dated October 23, 2012. The legal standing of BPKP, in calculating state financial losses in the case of procurement of medical devices at Health Office of Pesisir Selatan Regency, was as auditor. The judge was guided by the calculation of state financial losses carried out by BPKP and used it as a basis for consideration of decisions.
\end{abstract}

Keywords: Finance and Development Supervisory Agency (BPKP); Supreme Audit Agency (BPK); Calculating State Financial Losses

\section{Introduction}

The birth of the reform movement which began in early 1998 was essentially a reflection of the desire of the people and people of Indonesia to make total corrections and introspection of various collective mistakes of the New Order regime. This was partly marked by the widespread abuse of power and the development of the practices of Corruption, Collusion and Nepotism (KKN). That has created an 
awareness of one very important thing, i.e. an effort to create a government that is transparent, accountable, and responsive or usually called good governance. Various practices of abuse of power and KKN carried out by the previous regime have fostered a tremendous enthusiasm for the Indonesian people to uphold a clean and authoritative government. Based on these considerations, it fosters encouragement and pressure for a legal reform step through the renewal of legal products and the creation of a system of supervision of the behavior of civil servants and state administrators. ${ }^{1}$

The People's Consultative Assembly (MPR) responded to these demands by issuing the Decree of the People's Consultative Assembly (MPR) No. XI/MPR/1998 concerning the Implementation of a State that is Clean and Free of Corruption, Collusion and Nepotism (KKN). Then the Government and the People's Trustee Council (DPR) outlined the MPR's provisions in Law No. 28 of 1999 concerning State Organizers who are Clean and Free of Corruption, Collusion and Nepotism (KKN). The legal reform step in the context of creating good governance was then followed by amending the Law No. 3 of 1971 became Law No. 31 of 1999 concerning Eradication of Corruption Crime. Then, it was amended and supplemented by Law No. 20 of 2001 concerning Amendment to Law No. 31 of 1999 concerning Eradication of Corruption Crime. ${ }^{2}$

One element of criminal acts in the Corruption Law is "state financial losses" as stipulated in Article 2 Paragraph (1) and Article 3 of Law No. 31 of 1999 concerning Corruption Crime as amended by Law No. 20 of 2001 concerning Amendment to Law No. 31 of 1999. It requires financial calculations to determine the amount of state losses. ${ }^{3}$

Calculation of state financial losses is also needed to determine the amount of substitute money to be paid by the convicted person. In this case, in addition to being subjected to basic and additional criminal penalties in the Criminal Code, convicts of corruption can also be sentenced to additional penalties in the form of payment of replacement money as stipulated in Article 18 Paragraph (1) letter b of Law No. 31 of 1999 concerning Corruption Crime as amended by Law No. 20 of 2001.

In relation to proving the element of "detrimental to state finances", law enforcers usually request agency assistance or cooperate with relevant agencies that have expertise in financial audits, i.e. the Supreme Audit Agency (BPK) or the Financial and Development Supervisory Agency (BPKP). Both agencies have auditors who have expertise in conducting investigative audits and calculating financial problems. In practice, law enforcers usually ask for assistance or cooperate with BPKP in auditing state financial loss calculations with the consideration that the BPKP can conduct audits faster and does not require a long time if the audit is requested from the BPK.

There are multiple interpretations between law enforcement officers (Police, Attorney Advocates) as well as differences of opinion between the Constitutional Court (MK) and the Supreme Court (MA) related to the institution authorized to calculate the financial losses of the country. This can be used as a gap by the defendant/ legal counsel to escape corruption. In addition, the Constitutional Court's decision is lately often not followed by Court judges or the Supreme Court (MA). This can also make it difficult for the Public Prosecutor to prosecute corruption cases on the basis that the audit or calculation of state financial losses is carried out by the BPKP. This is the same as what happened in the trial case No. 31/Pid.Sus-TPK/2016/PN.Pdg related to corruption in the procurement of medical devices by Defendant Vera Aldilla Roza, ST who was tried in the Corruption Court in the District Court Padang. In the trial of corruption, the state finance expert presented by the defendant/ legal counsel said that the BPKP was not

\footnotetext{
${ }^{1}$ Rony Saputra, “Corporate Liability in Corruption Crime,” Jurnal Cita Hukum UIN Syarif Hidayatullah, 2015, page 23.

${ }^{2}$ Ibid., page 24.

${ }^{3}$ Rahmy Putri Yulia, "The Role of the BPK (Audit Board of Indonesia) and BPKP (Financial and Development Supervisory Agency) in Calculating State Financial Losses in the Context of Dealing with Corruption Cases, ” Jurnal Bina Adhyaksa, 2016, page 136 .
} 
authorized to calculate state losses by arguing that the agency authorized to calculate state financial losses was the BPK because it had a higher legal umbrella, i.e. the 1945 Constitution. In addition, the state finance expert presented by defendant/ legal counsel said that the BPKP could only calculate the state financial losses if it received permission from the president.

After the release of the Circular of the Supreme Court (SEMA) No. 4 of 2016, how is the standing of the Financial and Development Supervisory Agency (BPKP) in calculating state financial losses in corruption cases? Based on the above description, the author is interested in conducting a study in a thesis about how the legal standing of the Financial and Development Supervisory Agency (BPKP) of the Representative of West Sumatra Province in Calculating State Financial Losses in Decision No. 31/Pid.Sus/TPK/2017/PN.Pdg on behalf of the defendant Vera Aldilla Roza, ST at the Corruption Court in the Padang District Court.

\section{Research Method}

Legal research in the writing of this thesis uses a normative juridical approach. It is a study that approaches the legislation (statute approach) and the case (case approach). ${ }^{4}$ A normative study must certainly use a statute approach, because it will examine various legal rules that are the focus and central theme of a research. ${ }^{5}$ In addition, this is a descriptive analysis because it wants to express or describe legislation relating to legal theories for the research object. Data collection techniques used in this study include literature studies. It involves: (1) primary legal material in the form of main legal material consisting of legal rules starting from the 1945 Constitution, legislation and jurisprudence collected through library studies and court decisions, (2) secondary legal material in the form of legal material that is not binding but explaining primary legal materials such as legal journals, research results and documentation owned by agencies, institutions or legal experts, and (3) tertiary legal materials that support primary and secondary legal materials such as the Indonesian Language Dictionary and legal dictionaries that help translate legal terms. Then, interviews are also used to find out more about the cases discussed in this thesis. The author conducted an interview with one of the Prosecutors from the District Prosecutor's Office of Pesisir Selatan who handled the case. This interview was conducted only as an analysis reinforcer. Legal materials in library research are processed through qualitative analysis to answer research problems. Qualitative data analysis is a method of research to produce descriptive analysis data; i.e. about what was stated by the respondent in writing or verbally where the real behavior was researched and studied as something intact. ${ }^{6}$ After the data analysis is carried out, the results will be presented descriptively by telling and describing it as it is in accordance with the problems examined in the writing of this thesis.

\section{Results and Discussion}

\section{Position Case}

In 2012, the Pesisir Selatan District Health Office carried out Procurement of Medical Equipment for Community Health Centers whose funds were sourced from the 2012 Special Allocation Fund (DAK) in Health as stated in the Budget Implementation Document at the Regional Work Unit (DPA-SKPD) at the Pesisir Selatan District Health Office 2012 No. 1.02.102.01.25.06.52 dated 12 January 2012 with a budget allocation of IDR 1,500,000,000 (one billion five hundred million rupiah). To carry out this

\footnotetext{
${ }^{4}$ Peter Mahmud Marzuki, Legal Research, Jakarta, Kencana, 2009, page 26.

${ }^{5}$ Johny Ibrahim, Theory \& Methodology of Normative Legal Research, Malang, Bayumedia Publishing, 2010, page 93.

${ }^{6}$ Soerjono Soekanto and Sri Mamuji, Normative Legal Research: A Brief Review, Jakarta, PT Raja Grafindo, 2007 , page 12.
} 
activity for Provincial/ District/ City Governments in the management and use of the Special Allocation Fund, the Minister of Health of the Republic of Indonesia issued Regulation of the Minister of Health of the Republic of Indonesia No. 2494/MENKES/ PER/XII/2011 concerning Technical Guidelines for the Use of Special Allocation Funds for the Health Sector of the Republic of Indonesia. The Technical Guidelines stipulate the standards of equipment and logistics of the Village Health Post (Poskesdes), which are equipment and logistics which must be at least 76 Village Health Posts (Poskesdes). Especially in the Province of West Sumatra, the term Village Health Post (Poskesdes) is replaced by the term Nagari Health Post (Poskeri). To carry out this activity, Abdul Kani, SKM, MPH Call Kani (Head of Health Services for Facilities and Infrastructure at the Health Office in Pesisir Selatan District) was appointed as a witness and the Budget User Proxy (KPA) who served as a Commitment Making Officer (PPK) with Regent Decree No. 900/319/ Kpts/BPT-PS/2012 dated 23 August 2012. Then, Vera Aldilla Roza, SH Binti Asril Idrus was appointed as Contractor/ Provider of Goods for Procurement of Medical Devices at the Health Office in Pesisir Selatan District 2012, as Director of CV Nassya based on the Agreement/ Contract No. 21/Kontrak/ DAK/DK-PS/IX/2012 dated 10 September 2012 with a contract value of IDR 1,340,148,000 (one billion three hundred forty million one hundred and forty eight thousand rupiahs). After signing the contract, an advance payment was made to Vera Aldilla Roza, SH for $30 \%$ of the contract value of IDR 402,044,400 (four hundred two million forty-four thousand four hundred rupiah). Furthermore, $100 \%$ payment is made through the Bank Nagari account at Payakumbuh Branch Office on behalf of Vera Aldilla Roza, SH for IDR 938,103,600 (nine hundred thirty-eight million one hundred three thousand six hundred rupiah). Vera Aldilla Roza, SH must carry out activities as stipulated in contract No. 21/Kontrak/ DAK/DK-PS/IX/2012 dated 10 September 2012.

In its implementation, Vera Aldilla Roza, SH did not carry out the obligations by not delivering goods in the form of: 1 (one) obgyn bed unit and 1 baby resuscitation unit. Vera Aldilla Roza, SH also took unfair advantage. Based on the Explanation of Article 66 paragraph (8) of the Presidential Regulation No. 54 of 2010 concerning Procurement of Government Goods/ Services, it is stated that profits and reasonable overhead costs for construction work are a maximum of $15 \%$ (fifteen percent). However, based on the purchase invoice for the procurement of medical devices purchased from CV Nassya, it was only IDR 815,487,811 (eight hundred fifteen million eight hundred eleven thousand rupiah) including Value Added Tax (VAT). The price of the CV Nassya contract is IDR 1,340,148,000 minus IDR $815,487,811=$ IDR $524,660,189$ or $29.15 \%$ (twenty-nine and fifteen percent). That is an unfair advantage and greater than the provisions of Presidential Regulation No. 54 of 2010 concerning Procurement of Government Goods/ Services, i.e. 29.15\% minus 15\% $=14.15 \%$ (fourteen point fifteen per cent). In this case, it is an unnatural advantage. Based on the Audit Report from BPKP Representative of West Sumatra Province No. No. SR-866/PW03/5/2015 dated April 20, 2015 concerning Audit Report in the Framework of Calculation of State Financial Losses (PKKN) for Alleged Corruption in the Procurement of Medical Devices for Community Health Centers in the Health Service Environment in Pesisir Selatan District 2012, there is a state financial loss of IDR 379,068,182 (three hundred seventy nine million sixty eight thousand one hundred and eighty two rupiah).

\section{Analysis of Decisions}

Case of Procurement of Medical Devices for Community Health Centers in the Health Office in Pesisir Selatan District 2012 with the suspect Vera Aldilla Roza, ST was conducted based on investigations and conducted by the Regional Police of West Sumatra Cq Subdit III/Tipidkor Ditreskrimsus in 2014. In proving state financial losses, investigator of Subdit III/Tipidkor Ditreskrimsus of West Sumatra Regional Police, based on Letter of Head of West Sumatra Regional Police No. R/344/VIII/2014/Ditreskrimsus dated August 5, 2014, requested the Calculation of State Financial Losses to the Financial and Development Supervisory Agency (BPKP) of the Representatives of West Sumatra 
Province. Furthermore, at the request of the West Sumatra Regional Police Investigator, in accordance with the mechanism for calculating state financial losses, the following procedures were carried out:

1. Audit request for calculating state financial losses for the procurement of medical devices for Community Health Centers in the Health Office in Pesisir Selatan District 2012;

2. Exposure to West Sumatra Regional Police investigators held on 15 August 2014;

3. Evaluation of the evidence obtained by the investigator;

4. Request additional evidence and other documents for calculating state financial losses to investigators;

5. Issuance of the Letter of Assignment by the Head of BPKP Representative of West Sumatra Province to conduct an audit in the context of calculating the state financial loss for the case after the review of the document was carried out;

6. Review of documents relating to alleged cases of corruption;

7. Research on the results of the Report of Examination (BAP) made by the West Sumatra Derah Police investigator against witnesses involved in the alleged corruption case;

8. Identification and analysis of irregularities that occur in cases of alleged Corruption Crimes related to the calculation of state financial losses;

9. Calculation of state financial losses incurred;

10. Exposure to audit results in the context of calculating state financial losses to Investigators from the West Sumatra Regional Police on April 2015.

Theodorus M. Tuanokota formulated at least 5 (five) methods for calculating state financial losses as follows:

1. Overall loss with a number of adjustments;

2. Difference between contract price and cost of purchase or cost of production;

3. Difference between contract and price or certain comparative value;

4. Receipts that are state rights but not remitted to the state treasury;

5. Expenditures that are not in accordance with the budget used for personal or certain parties.

Furthermore, according to Theodurus M. Tuanokota, state financial losses can be mapped in the state financial loss tree or referred to by R.E.A.L Tree. It contains a branch of state financial losses relating to Receipt, Expenditure, Assets, and Liability.

The methods used by the Financial and Development Supervisory Agency (BPKP) in calculating state financial losses for this case are as follows:

1. Calculating the payment received by CV Nassya, i.e. the realization of a Fund Disbursement Order (SP2D) for payments to Nassya CV minus Value Added Tax (VAT) and Income Tax $(\mathrm{PPh})$;

2. Calculating the realization of goods purchases made by CV Nassya based on sales invoices/ order letters;

3. Calculating the value of a deficiency of 2 item items which includes obgyn bed and baby resuscitation table which are each minus 1 (one) compared to the contract;

4. Calculating the amount of state financial losses by subtracting the amount of payment received by CV Nassya with the value of the realization of the purchase of goods made by CV Nassya then adding the results with the value of the lack of procurement of 2 (two) items of goods.

In accordance with letter No. SR-866/PW/03/05/2015 dated April 20, 2015, the Financial and Development Supervisory Agency (BPKP) of the Sumatra Province Representative sent a Report on the 
Audit of State Financial Losses (LHAPKKN) to the West Sumatra Provincial Police which was a followup to the letter West Sumatra Police Chief No. R/344/VIII/2014Ditreskrimsus dated August 5, 2014 for Alleged Corruption in the Procurement of Medical Devices for Community Health Centers in the Health Office in Pesisir Selatan Regency 2012 with a value of State Financial Losses of IDR 379,068,182 (three hundred seventy nine million sixty eight thousand one hundred and eighty two rupiah).

On the basis of the Audit Report on the Calculation of State Financial Losses (LHAPKKN) from the Financial and Development Supervisory Agency (BPKP) of the Province of West Sumatra, the Public Prosecutor at the Pesisir Selatan District Prosecutor's Office handed over the case for prosecuting Vera Aldilla Roza, ST at the Corruption Court in the Padang District Court on charges: Primary, it is violating Article 2 Paragraph (1) Jo Article 18 paragraph (1) letter a or b of the Law of the Republic of Indonesia No. 31 of 1999 concerning Eradication of Corruption Crimes which has been amended and added to become Law of the Republic of Indonesia No. 20 of 2001 concerning Amendment to the Law of the Republic of Indonesia No. 31 of 1999 concerning Eradication of Corruption Crime Jo Article 55 paragraph (1) to 1 of the Criminal Code and Secondary, it is violating Article 3 Jo Article 18 paragraph (1) letter a or b of the Law of the Republic of Indonesia No. 31 of 1999 concerning the Eradication of Corruption Crimes which have been amended and added to become the Law of the Republic of Indonesia No. 20 of 2001 concerning Amendment to the Law of the Republic of Indonesia No. 31 of 1999 concerning Eradication of Corruption Crime Jo Article 55 paragraph (1) to 1 of the Criminal Code.

In the trial process related to proving elements of state financial losses or the state economy, based on interviews with the Public Prosecutor at the Pesisir Selatan District Prosecutor's Office regarding Vananda Putra, $\mathrm{SH}$ case, ${ }^{7}$ based on the expert statement from the West Sumatra Province Financial and Development Supervisory Agency (BPKP) submitted by the public prosecutor Pesisir Selatan Prosecutor's Office and State Loss Calculation Audit Report from the Financial and Development Supervisory Agency (BPKP) of West Sumatra Province No. SR-866/PW03/5/2015 on April 20, 2015 over Alleged Corruption in Procurement of Medical Devices for Community Health Centers in the Pesisir Selatan District Health Office, state losses due to the actions of defendants Vera Aldilla Roza, ST are IDR 379,068,182 (three hundred seventy nine million sixty eight thousand one hundred and eighty two rupiahs).

Furthermore, the Prosecutor Vananda Putra, SH, as the Public Prosecutor at the Pesisir Selatan District Prosecutor's Office, explained that after the examination of Defendant Vera Aldilla Roza, ST, the Judge then gave the defendant/ legal counsel the opportunity to submit a de charge witness namely Accounting and Audit experts based in Medan City, North Sumatra Province. According to Sudirman, an expert witness presented by the defendant in front of the trial, he explained that the State Financial and Development Supervisory Agency (BPKP) Calculation Audit of financial losses was not valid, because the BPKP was not authorized to calculate state losses. He argued that the agency authorized to calculate state financial losses is the Supreme Audit Agency (BPK) because it has higher legal umbrella is the 1945 Constitution and Article 10 Paragraph (1) and (2) Law No. 15 of 2006 concerning the Supreme Audit Agency (BPK) and Article 4 paragraph (4) of the Law of the Republic of Indonesia No. 15 of 2004 concerning Examination and Management of State Financial Responsibility (PPTJKN). In addition, the state finance expert presented by the defendant/ legal counsel mentioned that the Financial and Development Supervisory Agency (BPKP) could only calculate the state financial losses if it received direct permission from the president. Furthermore, based on the expert's opinion presented by the defendant, the Public Prosecutor in his explanatory statement stated that the Finance and Development Supervisory Agency (BPKP) of the Sumatra Provincial Representative had the authority to audit the state financial losses carried out by the BPKP with the consideration that the authority was regulated in Presidential Regulation No. 192 of 2014 concerning the Duties and Functions of the Financial and

\footnotetext{
${ }^{7}$ Interview with Vananda Putra, SH, a Public Prosecutor in the Case of Procurement of Medical Devices in Pesisir Selatan District on February 12, 2019.
} 
Development Supervisory Agency (BPKP which is strengthened by the Decision of the Constitutional Court (MK) No. 31/PUU-X/2012 dated 23 October 2012.

The decision of the Constitutional Court (MK) has expanded the interpretation of institutions/ agencies that are authorized to calculate the state financial losses, as follows:

1. The Supreme Audit Agency (BPK);

2. Financial and Development Supervisory Agency (BPKP);

3. Other agencies, for instance by inviting experts or by requesting material from the inspector general or agencies that have the same function from each government agency;

4. Other parties (including companies) who can address material truths in calculating state financial losses and/ or can prove cases that they are handling.

In this case, proving the element of loss of state finances, as contained in the judge's decision in the case of the defendant Vera Aldilla Roza, ST is as follows:

\section{Elements that Can Harm State Finance or State Economy}

It considers that the two elements of the object are not explicitly but are implicitly stated. The element of state finances and the state economy is the object of Corruption Crime Article 2 paragraph (1) including the object element of Corruption Crime in Article 3. The Corruption Conception in Indonesia mainly lies in the attack on legal interests regarding state finances (state wealth in the broadest sense) and the state economy.

According to Article 1 Number 1 of Law No. 17 of 2003 concerning State Finance, state finance is all rights and obligations of the state that can be valued with money, and everything in the form of money or goods that can be owned by the state due to the implementation of these rights and obligations.

Based on the explanation of Law of the Republic of Indonesia No. 31 of 1999 concerning Eradication of Corruption Crime, state finances are all state assets in any form that is separated or which is not separated including all parts of the state's assets and all rights and obligations arising from:

1. it is in the control, management and liability of officials from state and regional level institutions;

2. it is in the control, management and liability of State-Owned Enterprises/ Regional-Owned Enterprises, Legal Entity Foundations and State Capital Companies or Companies that include third party capital based on state agreements;

It considers that what is meant by harming the state finances or state economy is not explained in the general explanation or description of Article 2. However, BPK utilizes 4 (four) criteria related to state financial losses as follows:

1. Reduced state wealth and or increased state obligations that deviate from the provisions of the applicable legislation;

2. No receipt of part or all of the income that benefits state finances which deviates from the provisions of the applicable legislation;

3. Some or all of the expenditure that is a burden on state finance is greater or should not be a burden on state finances, which deviates from the provisions of the applicable legislation;

4. Any increase in state liabilities resulting from a commitment that deviates from the applicable legal provisions. 
All forms of state losses must be caused by acts that are against the nature of criminal law (wederrechtelijk), not caused by actions that contain nature against civil or state administrative law.

It considers that what is meant by the state economy is economic life which is structured as a joint venture based on the principle of kinship or independent community business based on government policies at the central and regional levels in accordance with the provisions of applicable laws aimed at providing benefits, prosperity and welfare to all people.

It considers that the activity of procuring Medical Devices for Community Health Centers in 2012 in Pesisir Selatan District was sourced from the Special Allocation Fund (DAK) in the Health Sector as stated in the DPA-SKPD of the South Sumatra District Health Office No. 1.02.102.01.25.06.52 dated 12 January 2012 with a budget allocation of IDR 1,500,000,000 (one billion and five hundred million rupiah);

It considers that the reference for the defendant is the rules regarding the procurement of goods and services (Presidential Regulation No. 54 of 2010);

It considers that the Self Estimated Price (HPS) compiled by Abdul Khani, Susilowati and Karnaini was IDR 1,499,000,000 (one billion four hundred and ninety million rupiahs) and based on the price and type of health equipment offered by the distributor without comparing local market prices;

It considers that the signing of the contract for the procurement of medical devices was then carried out on September 10, 2012 between witness Abdul Khani, SKM, MPH as Budget User Authority (KPA) and defendant Vera Aldilla Roza, ST as Director of CV NASSYA worth IDR 1,340,148,000 (one billion three hundred forty million one hundred and forty eight thousand rupiahs) with a period of 100 (one hundred) days starting from September 10, 2012 until December 18, 2012;

It considers that based on witness Abdil Khani, witness Nelfaridawati, confirmed by a letter of SP2D and acknowledged by the defendant Vera Aldilla Roza, ST as Director of CV. NASSYA, based on the funds disbursement document signed by witness Abdul Khani, witness Susilowati Nazaro, ST (the defendant in a separate file), disbursement of funds as stated by witness Nerfida, as Treasurer justified by witness Abdul Khani was acknowledged by Defendant Vera Aldilla Roza, ST as a partner;

It considers that that on 21 September 2012 the defendant Vera Aldilla Roza, ST received an advance of $30 \%$ from the contract value of IDR 402,044,400 in accordance with SP2D No. 03175/SP2DLS/1.02.01/Sept/2012 dated September 21, 2012 amounting to IDR 365,494,900 and SP2D No. 03176/Sp2D-LS/1.02.01/Sept/2012 dated September 21, 2012 amounting to IDR 36,549,491;

It considers that based on the Goods Inspection Report No. 440/1149/DAK-BAPB/DKPS/XII/2012 dated December 12, 2012, payment of 100\% on December 26, 2012 was IDR 938,103,600 according to SP2D No. 05350/SP2D-LS/1.02.01/Des/2012 dated December 26, 2012 and SP2D No. 05351/SP2D-LS/1.02.01/Des/2012 dated December 26, 2012;

It considers that based on the Audit Result Letter conducted by the BPKP Representative of West Sumatra Province on April 20, 2015, payments received by CV NASSYA with its director Vera Aldilla Roza, ST were down payment of IDR 402,044,400 then 100\% receipt of IDR 938,103. 600 amounting to IDR 1,340,148,000 which is further reduced by PPh and VAT of IDR 140,041,618 so that it becomes IDR 1,200,041,618;

It considers that the remaining excess price between the value in the contract and the goods with the actual price after deducting the profit of the partner and the operational costs incurred by the defendant based on the description of the beneficial elements above is IDR 158,567,718 (one hundred fifty eight million five hundred sixty seven thousand seven hundred and eighteen rupiah); 
It considers that based on the testimony of witness Nerfidawati, witness Abdul Khani, witness Susilowati and witness Karnaini, the defendant Vera Aldilla Roza, ST had received money for the procurement of medical equipment sourced from the 2012 Special Allocation Fund (DAK) as stated in the DPA-SKPD South Sumatra District Health Office No. 1.02.102.01.25.06.52. with a budget allocation of IDR 1,500,000,000 (one billion and five hundred million rupiah);

It considers that the funds transferred/ obtained by the defendant Vera Aldilla Roza, ST according to the rules were funds for Procurement of Medical Devices at Nagari Health Posts in Pesisir Selatan District. However, some of the funds turned out to be misused by the defendant so that the medical device program did not reach the expected target;

It considers that based on the description above, the element of state loss has been proven legally and convincingly.

It considers that from the above descriptions, the defendant's act fulfilled the element of the secondary indictment, i.e. violating Article 3 Jo Article 18, Law No. 20 of 2001 concerning Amendments to Law No. 31 of 1999 concerning Eradication of Corruption Crime Jo Article 55 of the Criminal Code.

It considers that the defendant is legally proven and convincingly guilty of committing a crime in the secondary indictment above. Therefore, the Panel of Judges certainly does not agree with the defense/ pledoi submitted by the defendant and the legal counsel so that the defense/ pleidoi submitted by the defendant or the legal counsel is legally groundless and must be ruled out.

It considers that the defendant was found guilty, then the defendant must be sentenced to be worth the blame.

It considers that during the hearing the defendant was in a healthy physical and spiritual condition. So, the defendant can take responsibility for the action.

It considers that Article 3 jo of Article 18 paragraph 91) letter b of Law No. 31 of 1999 as amended and supplemented by Law No. 20 of 2001 in the case of convictions contain the formulation of two basic penalties. In this case, in addition to being sentenced to imprisonment, the defendant can also be sentenced to a fine; with the provision that if the criminal fine is not paid by the defendant, it can be replaced with a prison sentence.

It observes the provisions of Article 3 Jo Article 18 of Law No. 31 of 1999 as amended and supplemented by Law No. 20 of 2001 concerning Amendment to Law No. 31 of 1999 concerning Eradication of Corruption Crime Jo Article 55 Paragraph (1) 1st of the Criminal Code and other relevant regulations.

The panel of judges tried the defendant as follows:

1. Stating that the defendant VERA ALDILLA ROZA, SH Binti ASRIL IDRUS, SH mentioned above, was not proven legally and convincingly guilty of committing a criminal act as in the primary indictment;

2. Freeing the defendant from the primary indictment;

3. Stating that the defendant VERA ALDILLA ROZA, SH Binti ASRIL IDRUS, SH mentioned above, was proven legally and convincingly guilty of committing corruption in a joint manner as in the secondary indictment;

4. Imposing criminal sentence against defendant VERA ALDILLA ROZA, SH Binti ASRIL IDRUS, SH with imprisonment for 1 (one) year and 6 (six) months and a fine of IDR 50,000,000 (fifty million rupiah) provided that the fine is not paid, it was replaced with a prison sentence for 1 (one) month; 
5. Sentenced the defendant to pay a replacement money of IDR $158,567,718$ (one hundred fiftyeight million five hundred sixty-seven thousand seven hundred and twelve rupiah) no later than one month after this decision had permanent legal force. If the defendant does not pay, the property will be confiscated and auctioned by the prosecutor to cover the replacement money. If the convict does not have sufficient assets, the convict will be sentenced to imprisonment for 2 (two) months;

6. Determining the period of arrest and the detention period that the defendant has served is deducted entirely from the sentence that had been handed down;

7. Determining that the defendant remains in detention;

8. Determining evidence items number 1 to 44 attached to case files;

9. Charging the defendant to pay a case fee of IDR 5,000 (five thousand rupiah).

It was decided this way in a deliberation meeting by the Panel of Judges at the Court of Corruption in the Class 1-A District Court of Padang on 29 December 2016 by Yose Ana Roslinda, SH, MH as Chief Judge of the Session, Mahyudin, SH, MH, and Zaleka H. GM SH, MH (Ad Hock) respectively as Member Judges. The decision was pronounced on Friday 30 December 2016 in the trial which was open to the public by the Panel of Judges assisted by Atramurni as Substitute Registrar and attended by Yuharmen Yakub, SH as the Public Prosecutor at the Pesisir Selatan District Prosecutor's Office and the Legal Advisor from the defendant.

Based on the consideration of proving the element of state financial losses above, it was concluded that the Audit Report on the Calculation of State Financial Losses conducted by the Financial and Development Supervisory Agency (BPKP) was used as the basis for consideration of the Judge's decision in proving the loss of state finances in the case of Procurement of Equipment Medicine at the Health Office. Regarding the total value of state financial losses, the Panel of Judges did not agree since based on the facts revealed at the trial, the Panel of Judges considered that the amount of state financial loss was IDR 158,567,718 (one hundred fifty-eight million five hundred sixty-seven thousand seven hundred and eighteen rupiahs). It is a common thing because the calculation of state financial losses by the relevant agencies is not always binding on the judge in determining the value of state financial losses and the amount of the substitute money. In addition, the defendant's legal counsel stated that the Calculation of State Financial Losses by the West Sumatra Representative Office of BPKP was invalid because it was not carried out by the authorized institution. In this case, the defendant's legal counsel stated that based on the Circular of the Supreme Court (SEMA) No. 4 of 2016, the agency authorized to declare the state financial losses is the Supreme Audit Agency (BPK). Regarding this matter, the Panel of Judges disagreed and dismissed the opinion of the defendant's legal counsel. It was the same as the existence of the Circular of the Supreme Court (SEMA) No. 4 of 2016 which states that the agency authorized to declare the state financial losses is only the Supreme Audit Agency (BPK) which has constitutional authority. In this case, the Panel of Judges did not take the Circular of the Supreme Court (SEMA) No. 4 of 2016 as a legal consideration in making decision.

\section{Conclusions}

Based on the results of the research and discussion above, the following conclusions can be drawn:

1. The standing of BPKP is in the realm of executive power where the regulation of authority related to the Calculation of State Financial Losses is contained in legislation, i.e. the Presidential Regulation No. 192 of 2014 concerning the Financial and Development Supervisory Agency (BPKP) and this authority was strengthened by the Decision of the Constitutional Court No. 31/PUU-X/2012dated October 23, 2012. 
1. The standing of BPKP, in calculating state financial losses in the case of the procurement of medical devices at the Health Office in Pesisir Selatan District, is the auditor. In this case, the judge refers to the results of the calculation of state financial losses carried out by the BPKP and makes it a basis for consideration of decisions. In this case, the judge did not agree with the value of state financial losses as stated in the BPKP State Financial Loss (LAHPKKN) Audit Report of West Sumatra Province in the amount of IDR 379,068,182 (three hundred seventy-nine million sixty-eight thousand one hundred and eighty-two rupiahs). However, based on the facts revealed at the hearing, the Panel of Judges counted for themselves the amount of state financial loss of IDR 158,567,718 (one hundred fifty-eight million five hundred sixty-seven thousand seven hundred and eighteen rupiahs). It is very reasonable because the calculation of state financial losses by the relevant agencies is not always binding on the judge in determining the value of state financial losses and the amount of the substitute money.

\section{References}

Diantha, I. M. P. (2016). Metodologi penelitian hukum normatif dalam justifikasi teori hukum. Prenada Media.

Harsono, B. (2008). Hukum Agraria Indonesia, Sejarah Pembentukan Undang-undang Pokok Agraria, Isi dan Pelaksanaannya, Jilid 1: Hukum Tanah Nasional. Djambatan, Jakarta.

Ibrahim, J. (2006). Teori dan metodologi penelitian hukum normatif. Malang: Bayumedia Publishing, 57.

Ismail, N.(2012). Arah politik hukum pertanahan dan perlindungan kepemilikan tanah masyarakat. Jurnal Rechts Vinding: Media Pembinaan Hukum Nasional, 1(1), 33-51.

Marzuki, M. (2017). Penelitian Hukum: Edisi Revisi. Prenada Media.

Marzuki, P. M. (2011). Penelitian Hukum, Kencana Prenada Media Group, Jakarta, 2011, hlm.141.

Mertokusumo, S. (2010). Hukum acara perdata Indonesia. Universitas Atma Jaya Yogyakarta.

Samudera, T. (2004). Hukum Pembuktian Dalam Acara Perdata, Alumni, Bandung.

Soemitro, R. H. (1990). Metodologi penelitian hukum dan jurimetri. Ghalia Indonesia, Jakarta, 167.

\section{Copyrights}

Copyright for this article is retained by the author(s), with first publication rights granted to the journal. This is an open-access article distributed under the terms and conditions of the Creative Commons Attribution license (http://creativecommons.org/licenses/by/4.0/). 